УДК 577. 486

\author{
Н. М. Цветкова, М. С. Якуба \\ Дніпровський національний університет імені Олеся Гончара
}

\title{
ОЦНКА ВПЛИВУ ДУБОВИХ НАСАДЖЕНЬ НА ЧОРНОЗЕМ ЗВИЧАЙНИЙ В УМОВАХ ПЛАКОРНОГО СТЕПУ ПРИСАМАР'Я ДНІПРОВСЬКОГО
}

Наведено результати дослідження комплексу слідових елементів у чорноземі звичайному різнотравно-типчаково-ковилевого степу та чорноземі звичайному лісопокращеному дубового насадження Присамар'я Дніпровського. Визначено абсолютні кількості слідових елементів (Pb, Mn, Cu, Ni, Ti, Pb) у грунті та показники кругообігу речовин і елементів у системі рослина-грунт-рослина у досліджених біогеоценозах. Наведено кількісну оцінку зміни вмісту елементів у грунті та показників кругообігу речовин і слідових елементів у деревному насадженні порівняно з різнотравно-типчаково-ковилевим степом. Показано, що кругообіг речовин у дубовому насадженні, порівняно зі степовим угрупованням, зміщений у бік гальмування за типом розвитку деревних екосистем лісової зони, що свідчить про те, що дубові насадження розвиваються у бік сильватизації або за лісовим типом.

Ключові слова: слідові елементи, чорнозем звичайний, чорнозем лісопокращений, дубове насадження, біологічний кругообіг речовин, вплив.

Представлены результаты исследования комплекса следовых элементов в чернозёме обыкновенном разнотравно-типчаково-ковыльной степи и чернозёме обыкновенном лесоулучшенном дубового насаждения Присамарья Днепровского. Определены абсолютные содержания следовых элементов (Pb, Mn, $\mathrm{Cu}, \mathrm{Ni}$, Ti, $\mathrm{Pb}$ в почве и паказатели круговорота веществ и элементов в системе растение-почва-растение в исследованных биогеоценозах. Дана количественная оценка изменения содержания элементов в почве и показателей круговорота веществ и следовых элементов в древесном насаждении по сравнению с разнотравно-типчаковоковыльной степью. Показано, что круговорот веществ в дубовом насаждении, по сравнению со степным сообществом, смещён в сторону торможения по типу развития древесных экосистем лесной зоны, что свидетельствует о том, что дубовые насаждения развиваются в сторону сильватизации или по лесному типу.

Ключевые слова: следовые элементы, чернозём обыкновенный, чернозём лесоулучшенный, дубовое насаждение, биологический круговорот веществ, влияние.

The investigations resaults of complecs trace elements in the black earth ordinary of the virgin steppe and the black earth by the oak plantation improvemental of Prisamarie Dnieprovsky are presented. The content of the trace elements $(\mathrm{Pb}, \mathrm{Mn}, \mathrm{Cu}, \mathrm{Ni}, \mathrm{Ti}, \mathrm{Pb})$ in the soil and the index of elements rotation in the plant-soil-plant sistem of investigstions biogeocenozis are determed.

The quantitatives estimation of the contents trace elements alteration in the soil of oak plantation compare with a virgin steppe have been demonstrated. The elements rotation in the oak plantation compared with a elements rotation in the virgin steppe. The differents in the elements circulations are evidenced by the brake to move and development of oak plantations in the forests type.

The relations correlation between trace elements and the ordinary black earth basys characteristics and the forest improvemental black earth are essential changes are demonstrated.

Keywords: trace elements, black earth ordinary, the forest improvemental black earth, oak plantation, the biological elements rotation, influence

Загальновизнано, що лісові екосистеми є найбільш важливим джерелом біорізноманіття планети, але антропогенне перетворення місцезростань та пряме знищення рослинного покриву на тлі глобальних змін клімату погрожує існуванню більше ніж половині лісових ресурсів світу [14; 16]. Ця загроза є особливо не-

(C) Н. М. Цвєткова, М. С. Якуба, 2017 
безпечною для степової зони України, де нині лісистість території найнижча та складає навіть для Північної Степової підзони менше 10 \% (для Північного Степового Придніпров'я - 6 \%). Тут природна лісова рослинність, яка локалізована у долинних та байрачних місцезростаннях, перебуває в особливій зоні ризику внаслідок прискорення аридизації й значного промислового та сільськогосподарського освоєння території. Лісові екосистеми Степової зони України зростають в умовах географічної невідповідності до умов існування та в умовах постійних змін кліматичних параметрів $[13 ; 15]$. Це робить лісові угруповання надзвичайно чутливими до коливань усіх факторів довкілля, тому першочерговим завданням при створенні лісових насаджень та полезахисних лісосмуг у степу є ретельне всебічне вивчення лісорослинних умов та підбір деревних порід і їх комбінацій, оптимальних для цих умов, з'ясування впливу створеного насадження на довкілля та його окремі компоненти $[6 ; 10]$.

У роботі досліджено вплив дубового насадження на плакорі на вихідні лісорослинні умови, а саме: чорнозем звичайний. Наведено кількісну оцінку цього впливу, розкрито зміни біокругообігу органо-мінеральних речовин та слідових елементів у системі грунт-рослина, згідно з класифікацією кругообігів речовин А. Є. Родіна та Н. І. Базилевич [2].

Історично природні ліси не могли розповсюдитися у плакорному степу, оскільки тут віками складалися умови для забезпечення біологічного кругообігу, що притаманний степовим угрупованням. При створенні лісу в степових умовах перед лісівниками постає завдання вкласти в межі степового біологічного кругообігу лісове угруповання, яке володіє особливими шляхами біологічного кругообігу та досить відмінними від степових річним коефіцієнтом зволоження, тривалістю вегетаційного періоду, накопиченням гумусу, реакцією грунтових розчинів, акумуляцією органічної речовини тощо. Завданням даної роботи є демонстрація зміни біологічного кругообігу речовин та слідових елементів у створеному в степових умовах дубовому насадженні, стосовно степового угруповання.

Об'єкти і методи дослідження. Для оцінки впливу лісової рослинності на грунтові характеристики в степових умовах у роботі досліджувався вміст слідових елементів у грунтах, опаді та підстилці (калдані) ділянки різнотравно-типчаково-ковилевого степу і дубового насадження, створеного на розораній степовій ділянці.

Основним методом роботи був біогеоценотичнй метод. Керівною ідеєю роботи були типологічні принципи лісів О. Л. Бельгарда [2]. Відбір підстилки та опаду проводилися за загальноприйнятою методикою [3]. Базові властивості грунтів (рН, вміст гумусу, хімічний склад, ємність поглинання) визначалися загальноприйнятими методами [1]. Слідові елементи у валовій формі визначали емісійним спектральним методом (метод 3-х еталонів), рухомі форми слідових елементів вилучали амонійно-ацетатним буфером і вимірювали їх вміст атомноабсорбційним методом [5; 7-9].

Як об'єкти дослідження було обрано ділянку різнотравно-типчаково-ковилевого степу та дубове насадження на плакорі.

Ділянка різнотравно-типчаково-ковилевого степу розташована на вершині вододільного плато між р. Самарою та балкою Сороковушкою (Присамарський біосферний стаціонар, Дніпропетровська обл., Новомосковський р-н.) із слабким схилом на $1,5^{\circ}$ північно-східної експозиції. Тип лісорослинних умов - суглинок сухий $\left(\mathrm{C}_{0-1}\right)$. У трав'яному ярусі превалюють Festuca rupicola Heuff, Poa nemoralis L, Thymus marschalianus Wild., Linum hirsutum L, Stipa Lessingiana trinet Rupr та інші. Грунт - чорнозем звичайний, карбонатний, малогумусний, середньо-суглинистий на лесовидних суглинках. Грунтові води - на глибині 40 м. Скіпання 3 46 см. За гранулометричним складом грунт важко-суглинистий. Кількість гумусу у верхньому горизонті дорівнює 4,3 \% і з глибиною зменшується. У верхніх 
горизонтах рН нейтральна, вглиб профілю реакція переходить у лужну. Співвідношення $\mathrm{Ca}: \mathrm{Mg}$ дорівнює 9:7. 3 глибиною частка $\mathrm{Mg}$ зростає незначною мірою $\mathrm{i}$ співвідношення падає до 7,0. Аналіз водної витяжки свідчить про відсутність засолення. Сухий залишок дорівнює $0,02-0,15 \%$. Водопостачання атмосферне. Режим зволоження характеризується локальним коефіцієнтом зволоження (ЛКУ):

$$
\text { ЛКУ }=\mathrm{P} / \mathrm{E}_{0}, \mathrm{P}<\mathrm{E}_{0} \text {, }
$$

де $\mathrm{P}$ - кількість річних опадів; $\mathrm{E}_{0}$ - сума вологи, яка випарувалася за рік.

Випаровуваність у районі дослідження значно перевищує річну кількість опадів, ЛКУ близько 0,6. Середня зольність степового калдану - 10,7 \%.

Дубові насадження 3 чагарниковим підліском створеноі на розораному вихідному різнотравно-бородачево-ковиловому степу плакору 3 невеликим нахилом північної експозиції $\left(2-4^{\circ}\right)$ за три кілометра від с. Всесвятське Новомосковського р-ну Дніпропетровської області. Вік насаджень 45 років. Зімкненість деревостою 0,5-0,9. Середня висота насаджень 12 м. Грунт - чорнозем суглинистий, середньовилужений, малогумусовий, слабозмитий. Материнська порода - леси. Зволоження - атмосферне. Грунтові води - на глибині 40 м. Тип садіння - рядовий. Відстань в рядах 0,75 м, між рядами - 1,5 м. У чагарниковому підліску - Acer tataricum L. та рідше Euonymus europaea L. Ряди Quercus robur L. чергуються з рядами чагарників. У біогеоценозі виражені дві основні парцели: дубово-чагарниково-мертвопокровна парцела та різнотравно-злакова. Дубовочагарниково-мертвопокровна парцела займає 85 \% площі насаджень, де у першому ярусі - Quercus robur L.; у другому - чагарники; травостій з причини високої затіненості практично відсутній або розвинутий слабо. Різнотравнозлакова парцела у “вікнах" займає 15 \% площі. У травостої превалюють Elytrigia repens (L.) Nevski., Poa compressa L., P. angustifolia L., Salvia verticillata L., Daucus carota L., Marrubium praecox Janka. Середньостатистична освітленність під пологом насаджень у мертвопокровній парцелі займає 1,0-1,7 \% від освітленності відкритого місця, в дубово-різнотравно-злаковій - 3,0-18,0 \%.

Результати та їх обговорення. У результаті проведених досліджень виявлено, що у чорноземі звичайному та чорноземі звичайному лісопокращеному вміст слідових елементів (табл. 1) варіює у широких межах: у чорноземі звичайному від 1,7 до 457,0 мг/кг грунту, у чорноземі звичайному лісопокращеному - від 1,2 до 763,0 мг/кг грунту. Коефіцієнт варіації у досліджених грунтах становить від 11 до $55 \%$.

\section{Таблиия 1}

Варіаційно-статистичні показники вмісту слідових елементів у корененасичених горизонтах чорноземів звичайного та лісопокращеного, $\mathrm{n}=34 ; \mathrm{p}=\mathbf{0 , 9 5}$

\begin{tabular}{|c|c|c|c|c|c|c|c|c|c|c|c|}
\hline \multirow[b]{2}{*}{ Біогеоценоз } & \multirow{2}{*}{$\begin{array}{c}\text { Група } \\
\text { грунтів } \\
\text { (3онн, 1961) }\end{array}$} & \multirow[b]{2}{*}{$\begin{array}{l}\text { Назва } \\
\text { грунту }\end{array}$} & \multirow[b]{2}{*}{$\begin{array}{l}\text { Пока- } \\
\text { зники }\end{array}$} & \multicolumn{8}{|c|}{ Слідові елементи } \\
\hline & & & & $\mathrm{Pb}$ & $\mathrm{Cu}$ & $\mathrm{Ti}$ & V & $\mathrm{Cr}$ & $\mathrm{Ni}$ & Mo & $\mathrm{Mn}$ \\
\hline \multirow{2}{*}{$\begin{array}{c}\text { Степова } \\
\text { цілина на } \\
\text { плакорі }\end{array}$} & \multirow[b]{2}{*}{ Елювіальна } & \multirow{2}{*}{$\begin{array}{l}\text { Чорнозем } \\
\text { Звичайний }\end{array}$} & $\mathrm{C}, \mathrm{мг} / \mathrm{Кг}$ & 3,2 & 7,5 & 10,0 & 39,0 & 120,0 & 43,0 & 1,7 & 510,0 \\
\hline & & & $\mathrm{V}, \%$ & 45 & 40 & 20 & 22 & 23 & 20 & 51 & 52 \\
\hline \multirow{2}{*}{$\begin{array}{c}\text { Штучні } \\
\text { дубові } \\
\text { насадження } \\
\text { на плакорі }\end{array}$} & \multirow[b]{2}{*}{ Елювіальна } & \multirow{2}{*}{$\begin{array}{c}\text { Чорнозем } \\
\text { звичайний } \\
\text { лісопокра- } \\
\text { щений }\end{array}$} & $\mathrm{C}, \mathrm{M \Gamma} / \mathrm{\kappa г}$ & 3,3 & 10,0 & 16,0 & 43,0 & 135,0 & 58,0 & 1,2 & 763,0 \\
\hline & & & $\mathrm{V}, \%$ & 48 & 36 & 15 & 21 & 11 & 45 & 55 & 33 \\
\hline
\end{tabular}

Кількісний вміст $\mathrm{Pb}, \mathrm{Cu}, \mathrm{Ti}, \mathrm{V}, \mathrm{Ni}, \mathrm{Mn}$ у чорноземі звичайному лісопокращеному дубових штучних насаджень значно вищий, ніж вміст вказаних елементів у чорноземі звичайному степової цілини, зворотну залежність зафіксовано для молібдену. Статистично не відрізняється у цих двох грунтах 
вміст хрому. Підвищений вміст низки слідових елементів у чорноземах звичайних лісопокращених свідчить про біогенну аккумуляцію слідових елементів рослинами лісового угруповання та позитивний середовищеперетворюючий вплив штучного лісу на степовий грунтовий покрив.

Розподіл слідових елементів за грунтовим профілем у чорноземах звичайному та звичайному лісопокращеному у роботі представлено у вигляді відносних одиниць, які вираховувались як коефіцієнт Кспп.

\section{Ксгп = С грунту/C грунтова порода.}

Такий вираз результатів дозволяє виключити вплив низки факторів на вміст елемента у грунті, а ступінь міграції елемента вздовж грунтового профілю визначається властивстями самого елемента, характером його сполук та умовами середовища: вологістю, температурою реакцією середовища, наявністю органічних та мінеральних сполук. Врешті-решт, слідові елементи поглинаються живими організмами, специфічно сортуються і одночасно перерозподіляються за компонентами біогеоценозу.

Відносний розподіл слідових елементів за профілем грунтів (табл. 2, 3) чорноземів звичайного та лісопокращеного характеризується своєрідним коливанням кількостей у різних генетичних горизонтах.

Таблиия 2

Відносний вміст (Ксгп) слідових елементів у чорноземі звичайному

\begin{tabular}{|l|c|c|c|c|c|c|c|c|c|}
\hline \multirow{2}{*}{ Горизонт, см } & \multicolumn{7}{|c|}{ Слідові елементи } \\
\cline { 2 - 11 } & $\mathrm{Pb}$ & $\mathrm{Mn}$ & $\mathrm{Ti}$ & $\mathrm{Cr}$ & $\mathrm{Ni}$ & $\mathrm{Mo}$ & $\mathrm{V}$ & $\mathrm{Cu}$ & $\mathrm{Zn}$ \\
\hline H 0-39 & 1,50 & 1,25 & 1,90 & 1,37 & 1,33 & 0,94 & 2,40 & 1,90 & 11,0 \\
\hline Hp 39-80 & 1,20 & 1,31 & 1,70 & 1,36 & 1,40 & 0,88 & 1,80 & 1,60 & 4,70 \\
\hline Ph 80-140 & 1,00 & 0,80 & 1,90 & 1,53 & 1,26 & 0,94 & 1,50 & 1,30 & 1,00 \\
\hline Pcarb 140-200 & 1,00 & 1,00 & 1,00 & 1,00 & 1,00 & 1,00 & 1,00 & 1,00 & 1,00 \\
\hline
\end{tabular}

Таблиия 3

Відносний вміст (Ксгп) слідових елементів у чорноземі звичайному лісопокращеному

\begin{tabular}{|l|c|c|c|c|c|c|c|c|c|}
\hline \multirow{2}{*}{\multicolumn{1}{|c|}{ Горизонт, см }} & \multicolumn{9}{|c|}{ Слідові елементи } \\
\cline { 2 - 11 } & $\mathrm{Mn}$ & $\mathrm{Pb}$ & $\mathrm{Ti}$ & $\mathrm{Cr}$ & $\mathrm{Ni}$ & $\mathrm{Mo}$ & $\mathrm{V}$ & $\mathrm{Cu}$ & $\mathrm{Zn}$ \\
\hline H 1-22 & 2,1 & 1,8 & 0,9 & 1,6 & 0,8 & 4,4 & 4,4 & 5,1 & 2,1 \\
\hline Hp 22-54 & 1,4 & 1,3 & 0,9 & 1,6 & 0,8 & 3,4 & 1,6 & 7,3 & 1,4 \\
\hline Ph 54-93 & 1,1 & 1,3 & 0,6 & 1,7 & 1,0 & 3,5 & 2,6 & 1,7 & 1,1 \\
\hline Pcarb 93-300 & 1,0 & 1,0 & 1,0 & 1,0 & 1,0 & 1,0 & 1,0 & 1,0 & 1,0 \\
\hline
\end{tabular}

У досліджених чорноземах виявлено відносно рівномірне зниження вмісту слідових елементів за профілем з максимумом у гумусованому горизонті. У чорноземі звичайному лісопокращеному (табл. 3) величини вмісту марганцю (Ксгп = $2,1)$ та ванадію $($ Ксгп $=4,4)$ значно вищі порівняно з аналогічними показниками для чорнозему звичайного (Ксгп = 1,21 та 2,4 відповідно), що свідчить про їх інтенсивну біогенну аккумуляцію рослинами лісових насаджень в умовах плакорного степу та про вплив лісу на степові грунти.

Як показник біологічного кругобігу речовин та елементів був досліджений опадо-підстилковий коефіцієнт - індекс інтенсивності, або швидкість кругообігу $[2 ; 12]$. Цей показник дає змогу з'ясувати життєвість, ступінь сильватизації біогеоценозу та прогнозування його подальшого розвитку.

Кругообіг речовин та слідових елементів вивчався у різнотравно-типчаковоковилевому степу та штучному дібовому насадженні на плакорі.

Як було зазначено вище, різнотравно-типчаково-ковилевий степ розташований на верхівці вододільного плато між р. Смарою та р. Сороковушкою. Типо- 
логічний шифр за Бельгардом ЧЗСГ, грунт - чорнозем звичайний малогумусний [4]. Тривале випасання худоби призвело до випадання з флористичного складу степового угруповання ковилів. Зараз вони зустрічаються у вигляді окремих куртинок. Основу травстою створює типчак бороздчатий (60 \%). У меншій кількості зустрічається бородач та ковила волосиста. 3 різнотрав'я - шавлія поникла, молочай болотний, деревій звичайний. Загальне покриття травостою 85 \%. Опадо-підстил-

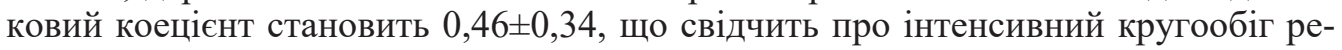
човин на степовій цілині. На тлі інтенсивного кругообігу речовин в умовах степу спостерігаються загальмовані кругообіги мангану (індекс 5,1), свинцю (індекс $5,1)$, сильно загальмований кругообіг титану (індекс 7,0); інтенсивний нікелю (індекс 0,63 ) та досить інтенсивний кругообіг хрому (індекс 0,02 ).

Біологічний кругообіг слідових елементів $\mathrm{Mn}, \mathrm{Ti}, \mathrm{Pb}$ та $\mathrm{Cu}$, порівняно з кругообігом речовин, зміщений у бік гальмування.

Штучне дубове насадження на плакорі з чагарниковим підліском створено на ділянці розпаханого вихідного різнотравно-типчаково-ковилевого степу.

Насадження розташовано на полакорі з незначним ухилом північної експозиції на відстані 3 км від с. Всесвятське Новомосковського району Дніпропетровської області. У чагарниковому підліску клен татарський та зрідка бересклет європейський. У біогеоценозі яскраво виражено дві парцели: різнотравно-злакова та мертвопокривна. Запаси слідових елементів ( $\mathrm{Ni}, \mathrm{Ti}, \mathrm{Mn}, \mathrm{Cu}, \mathrm{Pb}$ ) вищій у підстилці, ніж у опаді, запаси хрому в опаді та підстилці відносно однакові (табл. 4).

Таблиия 4

Запаси слідових елементів у опаді та підстилці дубового насадження на плакорі

\begin{tabular}{|l|c|c|}
\hline \multirow{2}{*}{ Слідовий елемент } & \multicolumn{2}{|c|}{ Запаси елемента, кг/га } \\
\cline { 2 - 3 } & підстилка & опад \\
\hline Мідь & $0,050 \pm 0,020$ & $0,011 \pm 0,005$ \\
\hline Нікель & $0,100 \pm 0,020$ & $0,049 \pm 0,008$ \\
\hline Хром & $0,017 \pm 0,006$ & $0,016 \pm 0,006$ \\
\hline Титан & $3,300 \pm 0,700$ & $0,930 \pm 0,080$ \\
\hline Манган & $2,900 \pm 0,600$ & $1,150 \pm 0,070$ \\
\hline Свинець & $0,070 \pm 0,020$ & $0,009 \pm 0,002$ \\
\hline
\end{tabular}

Тип кругообігу речовин - загальмований, індекс інтенсивності - 3,2 $\pm 0,5$. На загальному фоні загальмованого біокругообігу речовин формується інтенсивний кругообіг хрому (індекс $0,9 \pm 0,4$ ), сильно загальмований - свинцю (індекс $7,9 \pm 2,6)$, загальмований - міді $(4,3 \pm 1,3)$, нікелю $(3,6 \pm 1,6)$, титану $(3,7 \pm 0,3)$ та мангану $(2,6 \pm 0,5)$.

Висновки. Порівняльний аналіз показників кругообігу речовин та слідових елементів різнотравно-типчаково-ковилевого степу та штучного дубового насадження на плакорі, створеного в умовах степової зони, показав, що дубове насадження значно змінює елементний склад грунтів та швидкість кругообігу речовин у системі рослина-грунт-рослина в бік гальмування та наближає його до лісового типу.

Вивчення кореляційних зв'язків між слідовими елементами та базовими властивостями чорнозему звичайного та чорнозему звичайного лісопокращеного показало значні зміни цих зв'язків у грунтах під пологом дубового насадження.

Розподіл слідових елементів у профілі грунтів Степової зони - чорноземі звичайному - відносно рівномірний з незначним підвищенням порівняно 3 грунтоутворюючою породою кількісного вмісту елементів у верхньому гумусованому горизонті. У чорноземі звичайному лісопокращеному розподіл елементів аналогічний розподілу у профілі чорнозему звичайного, але з більш високою аккумуляцією елементів у верхньому гумусованому грунтовому шарі. 


\section{Бібліографічні посилання}

1. Аринуикина $\boldsymbol{E}$. В. Руководство по химическому анализу почв. Москва: МГУ, 1970. $478 \mathrm{c}$.

2. Базилевич Н. И., Родин Л. Е. Продуктивность и круговорот элементов в естественных и культурных фитоценозах. Биологическая продуктивность и круговорот химических элементов в растительных сообществах Ленинград: Наука.1971. С. 5-32.

3. Бельгард А. Л. Степное лесоведение. Москва: Лесн. пром., 1971. 336 с.

4. Белова Н. А., Травлеев А. П. Естественные леса и степные почвы (экология, микроморфология, генезис). Д.: ДГУ, 1999. 348 с.

5. Жовинский Е. Я., Кураева И. В. и др. Геохимия тяжелых металлов в почвах Украины Киев: Наукова думка, 2002. 214 с.

6. Замула X. П. Сучасний стан ведення лісового господарства в Україні. Агросвіт. 2013. № 19. С. 54-59.

7. Золотов Ю. А., Иванов В. А., Амелин В. Г. Химические тест-методы анализа Москва: Едиториал УРСС, 2006. 304 с.

8. Методические указания по определению тяжёлых металлов в почвах сельхозугодий и продукции растениеводства. (изд. 2-е, перераб. и доп.). Москва 1992. 241 с. $356 \mathrm{c}$.

9. Славин В. Атомно-абсорбционная спектрофотометрия. Ленинград: Химия, 1971.

10. Ткац Л. І., Гладун Г. Б. Оптимізація створення та вирощування захисних лісових смуг у степовій зоні України. Науковий вісник. 2003. Вип. 13.3. С. 245-253.

11. Фатєєв А. I. Фоновий вміст мікроелементів в грунтах України. За ред. Фатєєва А. І., Пащенко Я. В. Харків, 2003. 120 с.

12. Цветкова $\boldsymbol{H}$. $\boldsymbol{H}$. Особенности миграции органо-минеральных веществ и микроэлементов в лесных биогеоценозах Степной зоны Украины. Изд. 2-е, уточн. и доп. Днепропетровск: ООО «Стэнли», 2013. 216 с.

13. Functional traits and adaptive capacity of European forests to climate change. F. Bussotti, M. Pollastrini, V. Holland, W. Bruggeman. Environmental and Experimental Botany. 2015. Vol. 111. Issue 3. P. 91-113.

14. Positive biodiversity-productivity relationship predominant in global forests. J. Liang, T. W. Crowther, N. Picard, S. Wiser et al. Science. 2016. Vol. 354. Issue 6309. aaf8957.

15. Climate change and European forests: What do we know, what are the uncertainties, and what are the implications for forest management? M. Linder, J. B. Fitzgerald, N. E. Zimmermann, C. Reyer et all. Journal of Environmental Management. 2014. Vol. 146. Issue 12. P. 69-83.

16. Applying a framework for landscape planning under climate change for the conservation of biodiversity in the finnish boreal forest. A. Mazziotta, M.Triviño, O. P. Tikkanen, J. Kouki et al. Global Change Biology. 2015. Vol. 21. Issue 2, P. 637-651.

Надійшла до редколегії 25.11.2017 p.

УДК 582.916.61:631.526.3:631.529(477.63)

\section{И. Л. Домницкая}

Ботанический сад Днепровского национального университета имени Олеся Гончара

\section{COPTA РОДА SAINTPAULIA H. WENDL. В ЗАЩИЩЁННОМ ГРУНTE БОТАНИЧЕСКОГО САДА ДНУ}

На основании многолетних исследований показано, что род Saintpaulia H. Wendl. - один из наиболее популярных в цветоводстве защищённого грунта. В мире не существует единой методики сортооценки для его представителей. Интродукцию

(C) И. Л. Домницкая, 2017 